\title{
Investigation of the Beliefs and Assessment of the Security Feeling in Primary Education in Greece in Relationship to Rapid Onset Natural Disasters
}

\author{
Akylina MERELI ${ }^{1}$, Niki EVELPIDOU ${ }^{2}$, Assimina ANTONARAKOU ${ }^{3}$, Hara DRINIA ${ }^{4}$, Maria $^{3}$ \\ MERELI $^{5}$, Maria TZOUXANIOTI ${ }^{6}$
}

\begin{abstract}
The aim of the research is the awakening, participation and alertness of educators and students of Primary Education schools in Greece when it comes to rapid onset Natural Disasters pre-emption. The aim is the alertness of educators, as well as students of school units, so that they are able to face rapid onset natural disasters with prudence and composure, both during them, by putting themselves in the minimum possible danger, and after their finish, by taking part in the rehabilitation of "damages" of any kind. At an early stage, through the distribution of two questionnaires, one for educators and one for students, we invited the participants to answer questions relevant to their status and knowledge, when it comes to rapid onset natural disasters and their safe living in their school environment. In total, the participants exceeded two thousand $(2,000)$ persons. One thousand twenty seven $(1,027)$ educators, serving the Primary Education, and nine hundred eighty four (984) random students from all over the country, answered the digital questionnaires created through the application ArcGIS Survey123 (part of Geospatial Cloud by Esri), which is an integrated solution to the creation, distribution and analysis of survey data. From the statistical analysis of their answers, their beliefs regarding the subject examined arose and the proposed means of action is profiled, so that persons participating on the educational procedure can achieve their meaningful training, in order for them to feel safer and more aware, imparting their knowledge regarding rapid onset natural disasters. Their considering training programs about natural disasters necessary is clear, as the majority of them accept that any natural disaster is liable to occur while they are at school. The cond ucted research showed that the knowledge of educators and students regarding their responsibilities, as well as the necessary items and services which are essential during the occurrence of the natural phenomenon, as well as after its finish, seem to be inadequate.
\end{abstract}

(C) IJERE. All rights reserved

Keywords

Rapid onset natural disasters, Questionnaires, Primary Education in Greece, Assessment of safety feeling

\section{INTRODUCTION}

Danger is an inextricable part of human life and it is called "weij-ji" in Chinese, containing the semantics of possibility/risk and danger, indicating that the uncertainty is balanced between the benefits and losses. The avoidance of danger is unattainable, and it is consequently dealt with as a oneway street. The management of danger results in the mitigation of the threat against human life, property, and the environment (Smith, 2013). Prolepsis and management tactics are considered necessary with a view to protecting the citizens, as well as ensuring the financial prosperity and sustainable development (Dandoulaki, 2012). Danger, as Zalvanos (2002) has stated, is defined as a function of two parameters, i.e. the possibility of the occurrence of an undesirable event and the weight of the consequences that are likely to arise.

"Natural disasters" are an inextricable part of reality people live on Earth (Xanthopoulos, 2015). The term "disaster", according to Makropoulos (2006), describes the negative consequences provoked by the occurrence of an event. "Natural disasters", according to Ferris \& Petz (2012), are the 
consequences of the events, which are a consequence of natural hazards that exceed the ability of the local community to react and affect an area's social and financial development. An effort to define the term of "natural disaster" leads to the conclusion that it cannot be precisely defined, so that there is a commonly accepted definition. However, "disasters" share several common characteristics, which are commonly accepted, such as their deleterious impact on the natural and social environment, their sudden occurrence with or without outbreaks, as well as the ability to control their impacts before and after occurrence (Sapountzaki, 2007).

"Disasters are usually described as the combination of exposure to a threat, the contextual vulnerability conditions and the inadequacy of measures for the limitation or confrontation of potential negative consequences. The consequences of disasters include human losses, injuries, diseases and other negative repercussions on humans, numinous and social prosperity, combined with loss of property, reserve and services, cessation of social and financial activities, as well as environmental degradation" (Desai \& UNISDR, 2015). According to the Greek legislation (N. 3013/2002 article 2), "a disaster refers to every natural or technological phenomenon of prompt or slow evolution occurring in the terrestrial, marine or aerial environment, which provokes extensive unfavorable repercussions to both man and the human and natural environment".

Since the very old times, "natural disasters" tear down human societies and bear significant impacts on the economy, society, and security, and thus many challenges arise for local and regional authorities (Dandoulaki, 2012). Ratiani et al. (2012) state that children are the most vulnerable population group of our society, as they do not have access to information, which leads to ignorance and lack of capability to protect themselves and make the right decisions in difficult situations. Students react passively to the search of information, due to age and psychological features, and do not seem to comprehend the seriousness of the problem. Given that children spend daily a significant am ount of time in school, it is the school that shall play a significant role in their future development. The aim of the school environment is to aid in the students' development of basic skills, so that they can take the right decisions in crucial situations. The best way to limit the danger of disasters is to change the human behavior. With a view to achieving this goal, the following are proposed: 1 . the dissemination of information, especially among societies residing in high-risk areas, 2. the development of educational programs and 3. the development of a model of safe behavior and skills among the students. According to Balamir (2007) the value of risk reduction policy from natural disasters has been pointed out within the framework of dealing natural disasters and is a matter of international dialogue. Nowadays, many societies aiming reducing risk in advance, make efforts to reshape their institutional and organizational structures.

The aim of the two questionnaires created and distributed for the purpose of this research is to arise concern among educators and students about the existing knowledge and their attitude towards natural disasters, as well as the expression of their feelings and desires, when reflecting on a possible sudden, urgent occurrence of natural phenomenon. This event is a "breeding ground" for a future interaction.

\section{Situation of the Problem}

During the last years, Greece has faced many rapid onset situation, such as the destructive conflagration at Mati, Attica, summer 2018 (Lekkas, 2018; Kovács, 2019; Lagouvardos et al., 2019; Efthimiou et al., 2020; Vallianou et al., 2020; Garlichs et al., 2021; Zabaniotou et al., 2021), the torrent overflows at Mandra, Attica, autumn 2017 (Andreadakis et al., 2018; Diakakis et al., 2019; Speis, 2019; Varlas et al., 2019; Diakakis et al., 2020a, 2020b; Kanellopoulos et al., 2020), and Politika, Psachna and Vassilika, Euboea, summer 2020 (Lekkas et al., 2020; Karkani et al., 2021), common cataclysmic rainfalls, the sweeping typhon in Lefkada, August 2020, the earthquake and the consequent tsunami in Samos, October 2020 (Lekkas et al., 2020; Papadimitriou et al., 2020; Evelpidou et al., 2021), the great earthquake in Elassona, March, 2021 (Mavroulis et al., 2021; Lekkas et al., 2021a), the catastrophic fires in Attica 
and Evia in the summer of 2021 (Lekkas et al., 2021b) and many others. It is also worth mentioning that in almost all the aforementioned natural disaster cases, many human lives were mourned.

The place and time of occurrence of rapid onset natural disasters cannot be predicted. Most of the disasters mentioned took place at a time when educators and students were absent from the school units. Questions arise though, such as: "What would have happened if they had taken place during school lessons and especially when all educators and students were into the classrooms?", "Do their education and awareness suffice, so that they act in the right way and their lives are no threatened when possible?", "Is the participation of educators and students in training programs considered necessary?", "How do educators and students feel when reflecting on the possibility of their participation in awareness and meaningful training programs?".

\section{Aim of the Study}

The aim of the researchers through the collection of questionnaires is the investigation on the knowledge and beliefs of both educators and students of Primary Education in Greece regarding natural disasters. At an early stage, we aim at the assessment of the existent situation in Greece, as well as the feeling of these two groups of people. With that orientation, our questions focus on their quondam life within the school classrooms, their knowledge about the school setting and items, as well as the definition of the responsibilities of everyone who is a part of the school society. We also examine to what extent they consider the corresponding training of all participants necessary.

\section{METHOD}

The research is conducted through a descriptive research. The descriptive research aims at describing a past or current situation as is. The sample of this research consists of educators and students of Primary Education. The participants were randomly selected. The distribution of questionnaires through the internet followed, as the direct survey was difficult, given the coronavirus pandemic conditions and the mandatory quarantine of the citizens, as well as the remote education of students. From this distribution, almostall the desirable sample of educators was collected. The sample of students was directly collected through the assignment to Primary Education educators serving in different parts of the Hellenic territory, who were willing to participate, as well as to professors of Informatics, who were asked to perform this with their students, through the labora tory of Informatics of Primary Education schools.

For the data collection, two questionnaires were created, containing 12 questions for students and 13 questions for educators of all specialties, however only those being schooled or teaching at Primary Education schools. The questions included require answers about their knowledge on their responsibilities in case a rapid onset natural disaster occurs, how they are to act so that they put themselves in the minimum possible danger, if they have ever taken part in building evacuation exercises for several natural disasters, if they have ever been educated or wish to participate in educational programs, if they feel safe at school and other similar questions.

For the data analysis, ArcGIS Survey123 has been used. ArcGIS Survey123 is a form-centric solution for creating, sharing, and analyzing surveys. As part of the Esri's Geospatial Cloud, the ArcGIS Survey123 is an integrated solution to the creation, distribution, and analysis of survey data. Its functionality concerns the creation of digital forms, which share the operational logic and the proper data import rules for the conduction of surveys. Through the forms, valid data can easily be collected through internet or applications, the former being applied in portable systems. The descriptive statistical analysis was applied for the answers of educators, as well as students. Both the educators and the students were to answer closed-type questions, that is choose between a positive answer (Yes) and a negative answer ( $\mathrm{No})$.

\section{Results}


Here, the frequencies and the percentage frequencies of the answers of the educators and students who filled in the questionnaire (Table 1, Table 2).

Table 1. Frequencies of the answers of the educators.

\begin{tabular}{|c|c|c|c|}
\hline Questions & & $\mathbf{N}$ & $\%$ \\
\hline 1. Do you think that it is possible for a rapid & Yes, it is possible & 977 & 95,13 \\
\hline $\begin{array}{l}\text { conflagration, landslide etc.) to occur while } \\
\text { you are at school with your pupils? (Figure } 1 \text { ) }\end{array}$ & No, it is quite impossible & 36 & 3,51 \\
\hline 2. Have you been educated on how to deal & Yes & 464 & 45,18 \\
\hline with any natural disaster at your school? & No & 550 & 53,55 \\
\hline 3. Have you ever participated in building & Yes & 813 & 79,16 \\
\hline $\begin{array}{l}\text { evacuation exercises for the case of any } \\
\text { natural disasters }\end{array}$ & No & 202 & 19,67 \\
\hline $\begin{array}{l}\text { 4. If yes, do you think the exercises are easily } \\
\text { performed without the requirement of any }\end{array}$ & $\begin{array}{l}\text { Yes, they are easily } \\
\text { performed }\end{array}$ & 261 & 25,41 \\
\hline hard effort? & No, they require effort & 680 & 66,21 \\
\hline $\begin{array}{l}\text { 5. Do you think that the exercises need to be } \\
\text { repeated so that they are consolidated by }\end{array}$ & $\begin{array}{l}\text { Yes, they need to be } \\
\text { repeated }\end{array}$ & 998 & 97,18 \\
\hline students and teachers? & No, they do not & 14 & 1,36 \\
\hline 6. In case of a rapid onset natural disaster & Yes & 768 & 74,78 \\
\hline $\begin{array}{l}\text { during your lesson, do you know how to } \\
\text { react? }\end{array}$ & No & 257 & 25,02 \\
\hline $\begin{array}{l}\text { 7. Do you know what your and your } \\
\text { colleagues' responsibilities are (e.g. close the }\end{array}$ & Yes & 584 & 56,86 \\
\hline $\begin{array}{l}\text { tap valve, check the switchboard, use the fire } \\
\text { extinguisher etc.), in case a rapid onset event } \\
\text { takes place at school? }\end{array}$ & No & 430 & 41,87 \\
\hline $\begin{array}{l}\text { 8. In your school, do you know where to find } \\
\text { the switchboard, the tap valve, the fire }\end{array}$ & Yes & 598 & 58,23 \\
\hline $\begin{array}{l}\text { extinguisher, the first aid kit, the necessary } \\
\text { books, the student lists? (Figure 2) }\end{array}$ & No & 417 & 40,6 \\
\hline $\begin{array}{l}\text { 9. In case of a rapid onset natural disaster, do } \\
\text { you feel certain that you are properly }\end{array}$ & Yes & 294 & 28,63 \\
\hline $\begin{array}{l}\text { educated, and you and your students can stay } \\
\text { as safe as possible? }\end{array}$ & No & 719 & 70,01 \\
\hline $\begin{array}{l}\text { 10. Would you desire that there was planning, } \\
\text { so that you and your colleagues are educated }\end{array}$ & Yes & 996 & 96,98 \\
\hline $\begin{array}{l}\text { by experts on managing a rapid onset natural } \\
\text { disaster? }\end{array}$ & No & 19 & 1,85 \\
\hline $\begin{array}{l}\text { 11. Do you think that it would be necessary if } \\
\text { there was an organized program in the } \\
\text { framework of Versatile Zone or another }\end{array}$ & Yes, definitely & 980 & 95,42 \\
\hline $\begin{array}{l}\text { course, through which students would } \\
\text { annually be informed about the right actions } \\
\text { for a potential rapid onset event? (Figure 3) }\end{array}$ & No, it is not necessary & 32 & 3,12 \\
\hline $\begin{array}{l}\text { 12. In case of a rapid onset natural disaster } \\
\text { which will result in injuries, do you have the }\end{array}$ & Yes & 436 & 42,45 \\
\hline required knowledge to offer first aid? & No & 577 & 56,18 \\
\hline $\begin{array}{l}\text { 13. Do you know whom you should call for } \\
\text { the provision of immediate and valuable help }\end{array}$ & Yes & 717 & 69,81 \\
\hline $\begin{array}{l}\text { in case of a rapid onset disaster which you } \\
\text { cannot deal with alone? }\end{array}$ & No & 300 & 29,21 \\
\hline
\end{tabular}


The first 5 questions regard the educators' feeling when it comes to rapid onset natural disasters, through their experience and their lifetime within or outside of the school environment. Almost all of them, i.e. a percentage of $95 \%$, deem that the occurrence of a rapid onset natural disaster is possible while they work and supervise their students. Furthermore, they consider that building evacuation exercises are a procedure demanding effort (positive answers reach 66\%) and the repetition of the procedure is necessary in order for them to be effective when needed (positive answers reach 97\%).

Figure 1. Answers of the participants on the first question.

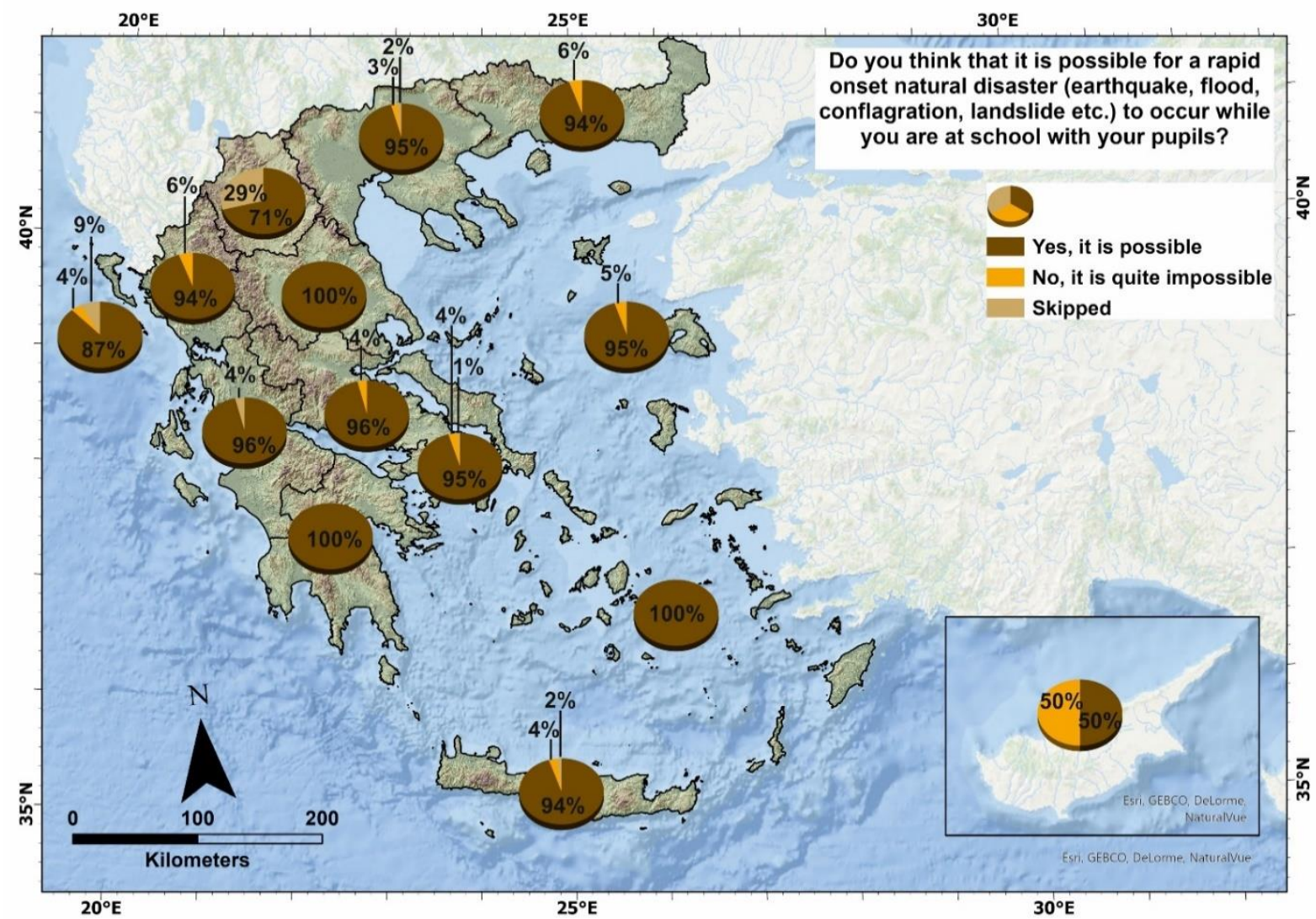

Questions 2 and 3 concern the educators' experience in the school reality up to today. Regarding this issue, answers are split, with slightly more than half of the educators (54\% percentage) deeming that they have not been educated, during their career, in dealing with any natural disaster. 8 out of 10 have participated in building evacuation exercises any natural disaster. Regarding the answer, there may have been a misunderstanding, as in Greece, building evacuation exercises take place, often once a year, only concerning earthquakes.

Questions 6, 7, 8, 9 regard the educators' knowledge when it comes to their and their colleagues' responsibilities while on duty, as well as the consequent feeling of safety or insecurity (Figure 2). Three out of four educators think that they know how to react properly in case of a rapid onset natural event. Slightly more than half of them (57\% percentage) deem that they are aware of everyone's responsibilities and where the tap valve, the fire extinguisher, the first aid kit and other items in case a rapid onset natural disaster takes place. Yet, question 9 reveals that seven out of ten educators do not feel secure and safe in case of a rapid onset phenomenon. This answer comes into contradiction with a previous answer that the educators know how to react. 
Figure 2. Answers of the participants on the eighth question.

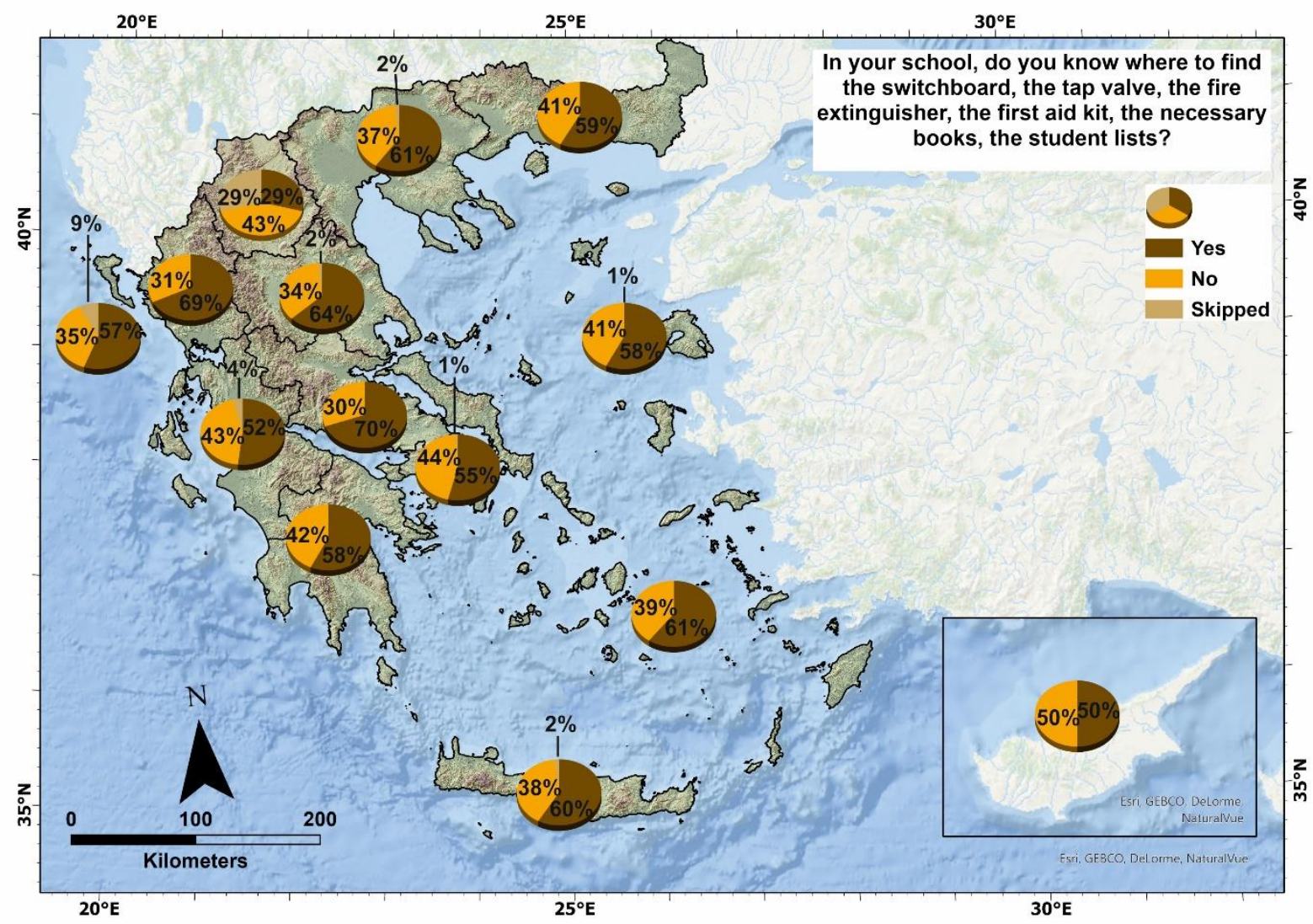

Questions 10 and 11 reflect the tendency and desire of educators for education regarding rapid onset natural disasters (Figure 3). The vast majority ( $97 \%$ and $95 \%$ respectively) wish for a training program incorporated within the school curriculum and consider that an organized, annual training program taking place in every school of the Greek territory is necessary. 
Figure 3. Answers of the participants on the eleventh question.

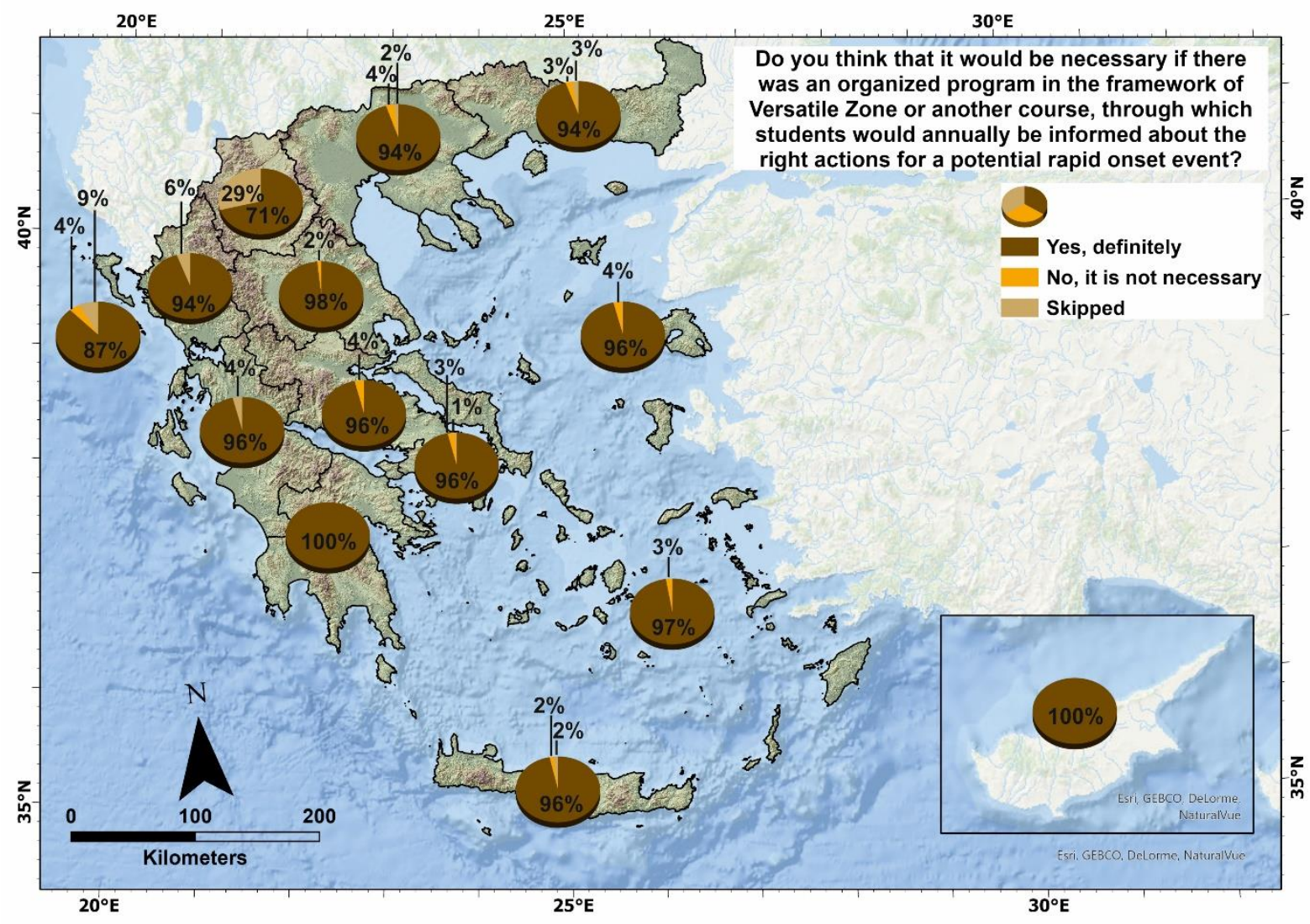

From the last two questions, one can see that more than half of the educators do not know how to offer first aid in case of an injury. Moreover, three out of ten are ignorant of the communication means for first aid. The geographical distribution of the sample (Figure 4 and Figure 5), as it is demonstrated in the following map, is also interesting. 
Figure 4. Educators' geographical distribution.

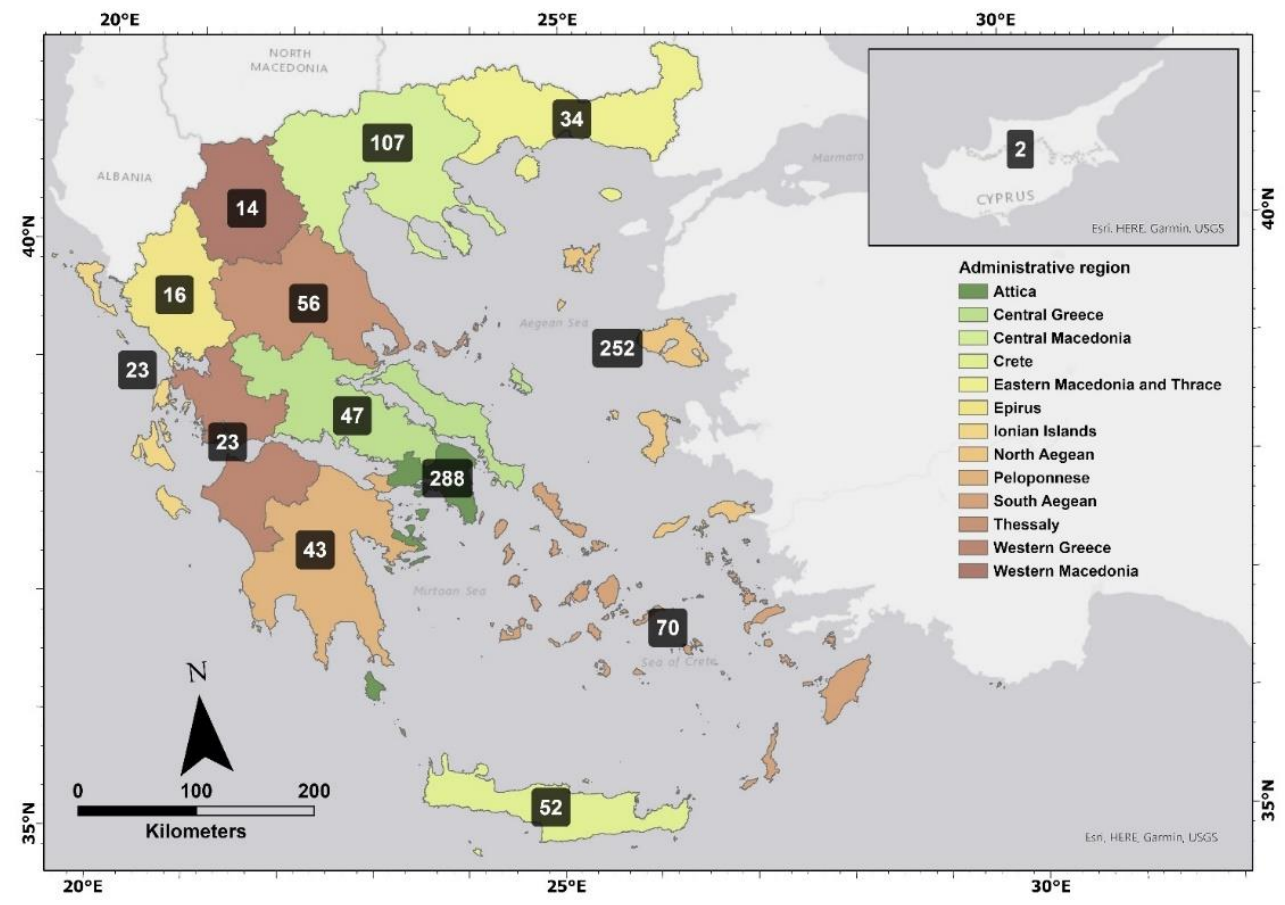

Figure 5. Learner's geographical distribution.

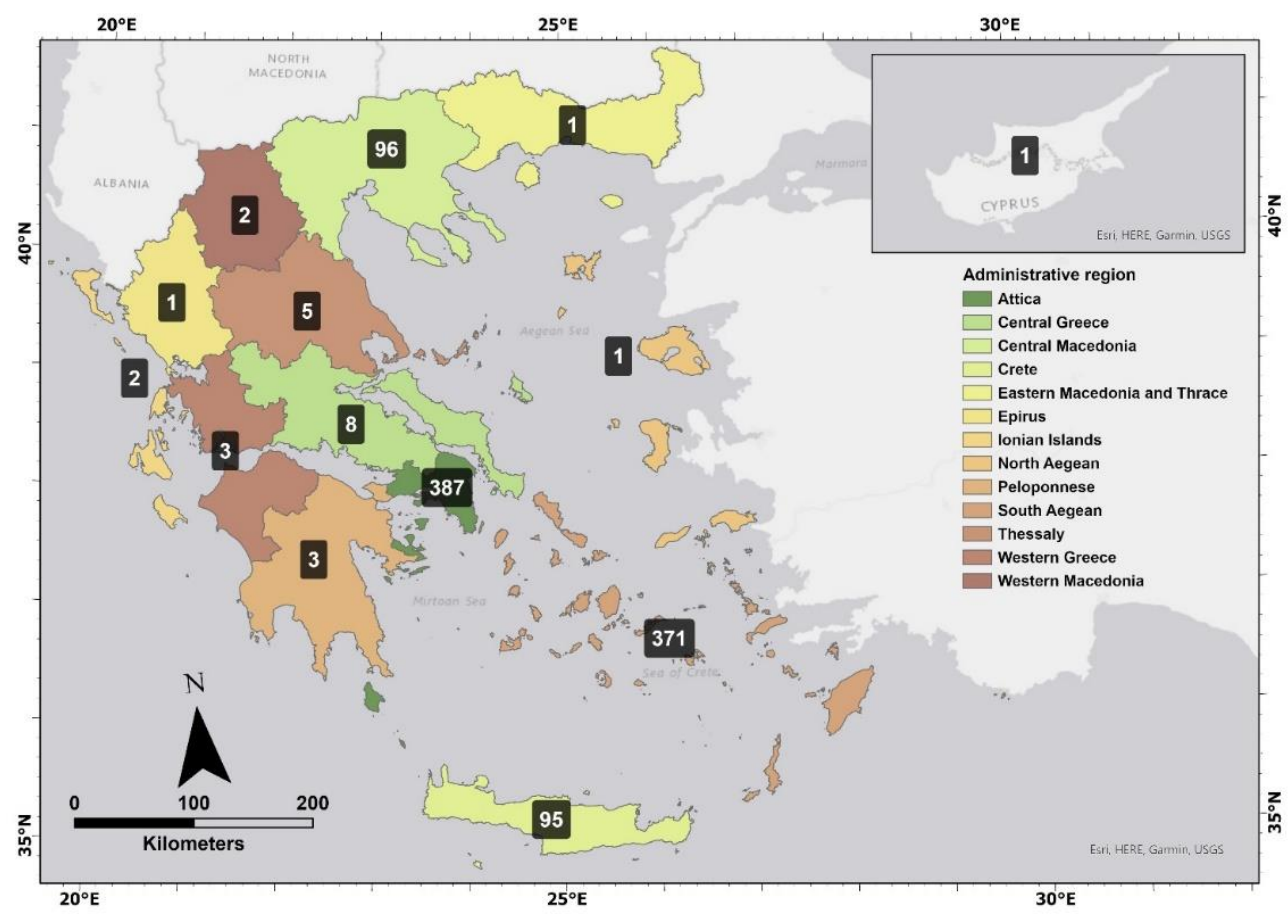


Table 2. Frequencies of the students' answers to every question.

\begin{tabular}{|c|c|c|c|}
\hline Questions & & $\mathbf{N}$ & $\%$ \\
\hline \multirow{2}{*}{$\begin{array}{l}\text { 1. Do you think that it is possible for a rapid onset natural } \\
\text { disaster (earthquake, flood, forest fire, landslide etc.) to } \\
\text { happen while you are at school? }\end{array}$} & Yes & 839 & 85,26 \\
\hline & No & 145 & 14,74 \\
\hline \multirow{4}{*}{$\begin{array}{l}\text { 2. Have you been taught, for as long as you are a student, } \\
\text { about how to deal with any natural disaster at your school? } \\
\text { 3. Have you ever taken part in school evacuation exercises for } \\
\text { the case of any natural disaster? }\end{array}$} & Yes & 799 & 81,2 \\
\hline & No & 180 & 18,29 \\
\hline & Yes & 834 & 84,76 \\
\hline & No & 147 & 14,94 \\
\hline \multirow{2}{*}{$\begin{array}{l}\text { 4. If so, do you think that you have understood how you } \\
\text { should react in case something rapid onset occurs? How you } \\
\text { should move, where you should stand? }\end{array}$} & Yes & 765 & 77,74 \\
\hline & No & 204 & 20,73 \\
\hline \multirow{4}{*}{$\begin{array}{l}\text { 5. In case a rapid onset natural disaster occurs during your } \\
\text { lesson, do you know how you should react? } \\
\text { 6. Do you know what you're and the rest of your classmates' } \\
\text { responsibility is and what the role of your teacher is? }\end{array}$} & Yes & 817 & 83,03 \\
\hline & No & 158 & 16,06 \\
\hline & Yes & 757 & 76,93 \\
\hline & No & 223 & 22,66 \\
\hline \multirow{2}{*}{$\begin{array}{l}\text { 7. In case of a rapid onset natural disaster, do you feel certain } \\
\text { that you are properly educated and that you, your } \\
\text { classmates, and your teacher can stay as safe as possible? }\end{array}$} & Yes & 655 & 66,57 \\
\hline & No & 321 & 32,62 \\
\hline \multirow{2}{*}{$\begin{array}{l}\text { 8. Would you like to participate in activities and games and } \\
\text { to be educated as properly as possible, so that you feel safer } \\
\text { and so that you know how you should react to a rapid onset } \\
\text { disaster, in order to be able to help yourself and others? }\end{array}$} & Yes & 853 & 86,69 \\
\hline & No & 119 & 12,09 \\
\hline \multirow{2}{*}{$\begin{array}{l}\text { 9. Can you offer first aid to someone who has been injured } \\
\text { during a rapid onset disaster? }\end{array}$} & Yes & 403 & 40,96 \\
\hline & No & 573 & 58,23 \\
\hline \multirow{2}{*}{$\begin{array}{l}\text { 10. Have you ever experienced a rapid onset natural disaster } \\
\text { while at home, the street, while camping or elsewhere? }\end{array}$} & Yes & 654 & 66,46 \\
\hline & No & 319 & 32,42 \\
\hline \multirow[b]{2}{*}{ 11. If yes, were you scared? } & Yes & 414 & 42,07 \\
\hline & No & 470 & 47,76 \\
\hline \multirow{2}{*}{$\begin{array}{l}\text { 12. Was there a coordinated and efficient reaction from the } \\
\text { authorities (Municipality, Fire Department, Police etc.)? }\end{array}$} & Yes & 451 & 45,83 \\
\hline & No & 445 & 45,22 \\
\hline
\end{tabular}

Just like the educators previously, students also radiate similar feelings when it comes to the possibility for a rapid onset natural disaster to occur while they are at school, as well a similar feeling of safety.

More specifically, the first seven questions regard the children's' relationship to education on natural disasters, as well as the consequent feelings. $85 \%$ of the students think that the occurrence of a rapid onset natural disaster is possible while they are at school. $81 \%$ think that they have been educated for a such situation and they have taken part in school evacuation exercises. Almost 8 out of 10 students state that they know how to react and $77 \%$ of them state that they know the responsibilities of those located inside the school building.

The consequent feeling of security and safety characterizes a $66,5 \%$ of the students. $87 \%$ of the students wish to participate in activities and games aiming at their education on rapid onset natural disasters.

Additionally, regarding their knowledge on how to offer first aid in case of an emergency, almost 6 out of ten children do not know how to offer first aid, whilst more than half of the children $(66,5 \%)$ 
have experienced a rapid onset natural disaster and $48 \%$ of them stated that they did not feel fear. Furthermore, almost half of the student's state that the reaction of those in charge (Municipality, Fire Department, Police etc.) was coordinated and efficient.

Finally, it is astonishing that, by comparing the answers of the two samples on the question about the alertness of the school regarding the management of a rapid onset event, the results are contradictionary. Teachers feel insecure when thinking of something like that (almost 3 out of 10 feel secure), whereas students feel secure, at a percentage of $66,57 \%$.

\section{DISCUSSION}

In contradiction with the fact that scientific knowledge and the evolution of technology, during the last years, regarding the Natural Disaster Management are significantly improved, the impacts of natural disasters have been increased at a global level (Lekkas, 2000). During the last thirty years, the financial losses owed to natural disasters, including earthquakes, tsunamis, floods, droughts, and hurricanes, reach four trillion dollars (Xanthopoulos, 2015). State governments, as well as National Organizations, make efforts to limit the increasing tendency of the impacts of natural disasters in several ways, such as the research enhancement, the improvement of the technological equipment and the application of tactics that can use and utilize the new trends regarding the three stages of the management of natural disasters, that is before, during and after the disaster, as much as possible (Lekkas \& Lozios, 2002).

All schools bear a major moral responsibility when it comes to ensuring a safe environment for the students and teachers through their level of education, awareness, and self-organization. As this level arises, the potential of avoiding or at least limiting the consequences of natural disasters is also increased. The prosecution of initiatives and training programs is also necessary for the enhancement of the school authorities', students' and teachers' feeling of security and alertness regarding disasters, in cooperation with the local authorities. It is essential that the responsibility the school bears on the students' life be well understood (Ratiani et al., 2012).

Selby \& Kagawa (2012) suggest that education contributes to the building of knowledge, skills, as well as the behavior of students by helping the preparation for, and management of, natural disasters. By studying the case of countries that have included several programs into their school curriculum in an effort to limit the disaster hazard, as well as cases where no priority is given to this, the prosecution of programs for the decrease of the disaster hazard is proposed, also taking the principles of sustainable development into account, so that future generations have a chance to prosper.

The same authors mention that Lesotho in southern Africa is one of the countries whose curriculum is reconsidered and transformed from a traditional model to a curriculum based on the development of skills, with a potential to incorporate programs for the decrease of the disaster hazard. Additionally, Malawi in eastern Africa has organized the school curriculum according to the "seven skill types", which will also include the decrease of the disaster hazard. Many of the studied countries expressed the significance of extracurricular activities for reducing the disaster hazard. The said countries include Armenia, Georgia, Kazakhstan, Russia, Turkey, Cambodia, Fiji islands, Indonesia, Laos, Myanmar, the Phillipines, Angola, Madagascar, France, Japan, New Zealand, the British Virgin Isles, Chile, Costa Rica, Cuba, Nicaragua, Peru, Egypt, Bangladesh, the Maldives, Nepal, Benin and Nigeria (Selby \& Kagawa, 2012).

In Greece, a study was conducted by Savelidis (2005), considering the alertness of Greek schools in case of management crises. This research shows that the school directors, who took part in the research and roughly had a 26-year work experience, have experienced two or three incidents, such as natural disasters, accidents, deaths, violence, political or social disturbances, which, according to them, bore a positive impact on the educational system, as well as their personal lives. Therefore, this tallies with the results of our research, whose samples agree on the fact that it is very liable for a rapid onset natural disaster to occur while they are at school. In addition, it is congruent with the fact that there is 
a feeling of safety regarding the alertness of the school unit. Less than half $(48 \%)$ in the first research think that the current educational system is capable of managing school crises. In our research, the percentage is even smaller, as almost 3 out of 10 educators think that they can deal with a rapid onset natural disaster. Therefore, the adults' feeling of safety, who are responsible for the school unit, is clear on both researches. It is worth mentioning that almost all directors of the first research $(91,51 \%)$ believe that an integrated crisis management system must be prosecuted for the Secondary education in Greece, which is also coincident with our research, as almost all teachers (97\%) deem that they want to be educated and wish for an organized training program for Primary education. Finally, this also talli es with the percentage of directors $(80 \%)$ who emphasize the significance of educating the administrative stuff and selected educators regarding crisis management. The consequent feeling of the samples of both researches is that in both tiers, the education of teachers on crisis issues including natural disasters is necessary.

The fact that natural disasters do not occur often renders the programming difficult. Problems arising less than once every generation - sometimes less than once every millennium - are easily overlooked (e.g. Haiti earthquake, 2010 (Bilham, 2010; Ripp et al., 2012; Pyles \& Svistova, 2015; Engle, 2018)). It is strange that the twentieth century, which was characterized by the most advance technology in human history, has experienced more deaths owed to natural disasters in comparison to any other century. It is possible that this century comes first in the number of deaths in comparison to the previous one, when the deaths reached 3,5 million (Schiermeier, 2005).

According Papagiannaki et al. (2019), the Greeks are anxious about natural disasters. This tallies with our research, as $95 \%$ of teachers and $85 \%$ of students think that a natural disaster can occur while they are at school. The research of the Observatory, $26 \%$ of the participants cannot even recall the number of emergency, which is also shown in our research, as 3 out of 10 teachers state that they do not know whom they should call for help in case of a rapid onset event. In the first research, $77 \%$ have not participated in any alertness exercise, except for exercises when they were students. This comes into full contradiction with our research, as 8 out of 10 educators state that they have participated in school evacuation exercises. The Observatory's research showed that those who have experienced a natural disaster are justifiably more concerned after it has occurred and are better prepared for another one. In our question towards the students, whether they have experienced a natural disaster, the answers show that $66 \%$ of them have experienced a natural disaster and half of them were not scared. According to the Observatory's research, Greeks show a mediate extent of trust towards the Authorities, i.e. they feel that they cannot be protected against a natural disaster. In a similar question posed to the students of our sample, i.e. whether those who experienced a natural disaster felt that the reaction of the authorities was co-ordinated, the answers were almost split in half. Half of the students stated that there is a co-ordinated reaction of the authorities towards natural disasters. The rest answered negatively. In conclusion, some results of the two researches converge, whereas a few diverge.

\section{Conclusions}

As a conclusion of the above observations, we noticed that many countries try to incorporate natural disasters into the curriculum, as they pose a rapid onset event that results in many fatalities first, and then costs exaggerate amounts of money. In Greece, the theoretical knowledge regarding rapid onset natural disasters is insufficient. Yet, the biggest problem is that there is little practical application of activities capable of offering actual help. $58 \%$ of the educators stated that they know well items of the school building such as the fire extinguishers, the tap valve, the switchboard and the first aid kit. The rest of them? The feeling of insecurity is clearly shown by all our sample. It is also auspicious that the school community feels the lack of education and wishes for it. This "desire" can lead to real and constant learning results. Therefore, this feeling is to be utilized.

As a result of the present research, other questions could be added to which a descriptive analysis of the participants' views would be requested to look into the analysis of the answers. In addition, a 
larger sample of responses could be collected. Finally, the availability of everyone for training could be utilized and so an appropriate training program could be created, which would be designed to be implemented in the meeting place of teachers and students, at school. Through the provision of knowledge, the objectives of the research could be achieved.

\section{Acknowledgements}

We would like to thank the scientific supervisor of the doctoral dissertation for its guidance and full support, as well as all the authors. In addition, all teachers, and students of Primary Education for their participation in the filling in the questionnaires that were prepared to promote the research.

\section{References}

Andreadakis, E., Diakakis, M., Nikolopoulos, E. I., Spyrou, N. I., Gogou, M. E., Katsetsiadou, N. K., Deligiannakis, G., Georgakopoulos, A., Antoniadis, Z., Melaki, M., Lekkas, E., \& Kalogiros, J. (2018). Characteristics and impacts of the November 2017 catastrophic flash flood in Mandra, Greece. European Geosciences Union General Assembly, 8-13.

Balamir, M. (2007). Seismic hazard and urban planning for their decreasing - Case study: Istanbul. In K. Sapountzaki (Ed.), Tomorrow in danger - Natural and technological disasters in Europe and Greece. Gutenberg.

Bilham, R. (2010). Lessons from the Haiti earthquake. Nature, 463(7283), 878-879.

Dandoulaki, M. (2012). Kallikratis, Civil Protection and Local Government. Hellenic Agency for Local Development and Local Government (In Greek). 10.1088/1751-8113/44/8/085201

Diakakis, M., Andreadakis, E., Nikolopoulos, E. I., Spyrou, N. I., Gogou, M. E., Deligiannakis, G., Katsetsiadou, N.K., Antoniadis, M., Melaki, M., Tsaprouni, K., Kalogiros, J., \& Lekkas, E. (2019). An integrated approach of ground and aerial observations in flash flood disaster investigations. The case of the 2017 Mandra flash flood in Greece. International Journal of Disaster Risk Reduction, 33, 290-309.

Diakakis, M., Boufidis, N., Grau, J. M. S., Andreadakis, E., \& Stamos, I. (2020a). A systematic assessment of the effects of extreme flash floods on transportation infrastructure and circulation: The example of the 2017 Mandra flood. International journal of disaster risk reduction, 47, 101542.

Diakakis, M., Deligiannakis, G., Andreadakis, E., Katsetsiadou, K. N., Spyrou, N. I., \& Gogou, M. E. (2020b). How different surrounding environments influence the characteristics of flash floodmortality: The case of the 2017 extreme flood in Mandra, Greece. Journal of Flood Risk Management, 13(3), e12613.

Efthimiou, N., Psomiadis, E., \& Panagos, P. (2020). Fire severity and soil erosion susceptibility mapping using multi-temporal Earth Observation data: The case of Mati fatal wildfire in Eastern Attica, Greece. Catena, 187, 104320.

Engle, J. (2018). Stories of tragedy, trust and transformation? A case study of education-centered community development in post-earthquake Haiti. Progress in Planning, 124, 1-34.

Evelpidou, N., Karkani, A., \& Kampolis, I. (2021). Relative sea level changes and morphotectonic implications triggered by the Samos earthquake of $30^{\text {th }}$ October 2020. Journal of Marine Science and Engineering, 9(1), 40.

Ferris, E., \& Petz, D. (2012). The year that shook the rich: A review of natural disasters in 2011. Brookings Institution-London School of Economics Project on Internal Displacement.

Garlichs, C., Diakakis, M., Mavroulis, S., Fuchs, S., \& Papathoma-Köhle, M. (2021). Vulnerability of buildings to wildfire. EGU General Assembly Conference Abstracts, EGU21-1173.

Greek Government Gazette, (2002). Low 3013, Upgrading of civil protection and other provisions (In Greek). Hellenic democracy. 1(102), 1527-1546. 
Kanellopoulos, T. D., Karageorgis, A. P., Kikaki, A., Chourdaki, S., Hatzianestis, I., Vakalas, I., \& Hatiris, G. A. (2020). The impact of flash-floods on the adjacent marine environment: the case of Mandra and Nea Peramos (November 2017), Greece. Journal of Coastal Conservation, 24(5), 1-17.

Karkani, A., Evelpidou, N., Tzouxanioti, M., Petropoulos, A., Santangelo, N., Maroukian, H., Spyrou, E., \& Ladiki, L. (2021). Flash flood susceptibility evaluation in human-affected areas using geomorphological methods - The case of 9th August 2020, Euboea, Greece. A GIS-based approach. GeoHazards, 2, 366-382.https://doi.org/10.3390/geohazards2040020

Kovács, K. D. (2019). Evaluation of burned areas with sentinel-2 using snap: the case of Kineta and Mati, Greece, July 2018. Geographia Technica, 14(2).

Lagouvardos, K., Kotroni, V., Giannaros, T. M., \& Dafis, S. (2019). Meteorological conditions conducive to the rapid spread of the deadly wildfire in eastern Attica, Greece. Bulletin of the American Meteorological Society, 100(11), 2137-2145.

Lekkas, E., Agorastos, K., Mavroulis, S., Kranis, H., Skourtsos, E., Carydis, P., Gogou, M., Katsetsiadou K. N., Papadopoulos, G., Triantafyllou, I., Agalos, A., Moraitis, S., Stamati, E., Psarris, D., Kaviris, G., Kapetanidis, V., Papadimitriou, P., Karakonstantis, A., Spingos, I., Kouskouna, V., Kassaras, I., Pavlou, K., Voulgaris, N., Mavrouli, M., Pavlides, S., Chatzipetros, A., Sboras, S., Kremastas, E., Chatziioannou, A., Kiratzi, A., Papazachos, C., Chatzis, N., Karakostas, V., Papadimitriou, E., Koukouvelas, I., Nikolakopoulos, K., Kyriou, A., Apostolopoulos, D., Zygouri, V., Verroios, S., Belesis, A., Tsentzos, I., Krassakis, P., Lymperopoulos, K., Karavias, A., Bafi, D., Gatsios, T., Karatzia, M., Gkougkoustamos, I., Falaras, T., Parcharidis, I., Papathanassiou, G., Evangelidis, C. P., Karastathis, V., Tselentis, G. A., Ganas, A., Tsironi, V., Karasante, I., Valkaniotis, S., Galanakis, D., Kostantopoulou, G., Theodoulidis, N., Karakostas, C., Lekidis, V., Makra, K., Margaris, V., Morfidis, K., Papaioannou, C., Rovithis, M., Salonikios, T., Papadopoulos, N., Kourou, A., Manousaki, M., \& Thoma, T. (2021a). The early March 2021 Thessaly earthquake sequence. Newsletter of Environmental, Disaster and Crises Management Strategies, 22, ISSN 2653-9454.

Lekkas, E., Carydis, P., Lagouvardos, K., Mavroulis, S., Diakakis, M., Andreadakis, Emm., Gogou, M. E., Spyrou, N. I., Athanassiou, M., Kapourani, E., Arianoutsou, M., Vassilakis, M., Parcharidis P. Kotsi, E., Speis, P. D., Delakouridis, J., Milios, D., Kotroni, V., Giannaros, T., Dafis, S., Kargiannidis, A., \& Papagiannaki, K. (2018). The July 2018 Attica (Central Greece) Wildfires - Scientific Report (Version 1.0). Newsletter of Environmental, Disaster, and Crisis Management Strategies, 8, ISSN 26539454.

Lekkas, E., Mavroulis, S., Gogou, M., Papadopoulos, G. A., Triantafyllou, I., Katsetsiadou, K. N., Kranis, H., Skourtsos, E., Carydis, P., Voulgaris, N., Papadimitriou, P., Kapetanidis, V., Karakonstantis, A., Spingos, I., Kouskouna, V., Kassaras, I., Kaviris, G., Pavlou, K., Sakkas, V., Karatzetzou, A., Evelpidou, N., Karkani, A., Kampolis, I., Nomikou, P., Lambridou, D., Krassakis, P., Foumelis, M., Papazachos, C., Karavias, A., Bafi, D., Gatsios, T., Markogiannaki, O., Parcharidis, I., Ganas, A., Tsironi, V., Karasante, I., Galanakis, D., Kontodimos, K., Sakellariou, D., Theodoulidis, N., Karakostas, C., Lekidis, V., Makra, K., Margaris, V., Morfidis, K., Papaioannou, C., Rovithis, E., Salonikios, T., Kourou, A., Manousaki, M., Thoma, T., \& Karveleas, N. (2020). The October 30, 2020 Mw 6.9 Samos (Greece) earthquake. Newsletter of Environmental, Disaster and Crises Management Strategies, 21, ISSN 2653-9454

Lekkas, E., Parcharidis, I., Arianoutsou, M., Lozios, S., Mavroulis, S., Spyrou, N-I., Antoniou, V., Nastos, P., Mavrouli, M., Speis, Ph., Katsetsiadou, K-N., Kranis, H., Skourtsos, Emm., Bakopoulou, A., Karalemas, N., Filis, Ch., Kotsi, E., Gogou, M., Diakakis, M., Carydis, P., Papadopoulos, I., Bafi, D., Karavias, A., Petani, A-K., Gkougkoustamos, I., Falaras, T., Tselka, I., Nikolidaki, M., Evelpidou, N., Tzouxanioti, M., Gavalas, Th., Cartalis, C., Philippopoulos, K., Polydoros, A., Mavrakou, Th., Argyris, I., Soukis, K., Laskari, S., Vassilakis, Emm., Kapourani, E., Andreadakis, Emm., Karatzaferis, O., Stavropoulou, M., Stamati, E., Zikeloglou, G., Menemenlis, D. (2021b). The July August 2021 Wildfires in Greece. Newsletter of Environmental, Disaster and Crises Management Strategies, 25, ISSN 2653-9454. 
Lekkas, E., Spyrou, N. I., Kotsi, E., Filis, Ch., Diakakis, M., Lagouvardos, K., Cartalis, C., Kotroni, V., Dafis, S., Vassilakis, E., Mavrakou, Th., Parcharidis, I., Sartabakos, P., Gogou, M. E., Katsetsiadou, A. N., Karagiannidis, A., Barsaki, V. Karavias, A., Bafi, D., \& Gougoustamos, I. (2020). The August 9, 2020 Evia (Central Greece) Flood. Newsletter of Environmental, Disaster and Crises Management Strategies, 19, ISSN 2653-9454.

Lekkas, L. E. (2000). Natural and Technological Disasters (2nd edition) (In Greek). ACCESS Pre- Press.

Lekkas, L. E., \& Lozios, S. G. (2002). Basic Principles and Applications of Business Planning for the Management of Natural Disasters and Technological Risks (In Greek).

Makropoulos, K. (2006). Natural Disasters: Earthquakes and Protection measures (In Greek). In 15 Concrete Conference, Technical Chamber of Greece (TEE-TCG), 25-27 October 2006, Alexandroulopi, Greece, 1-9.

Mavroulis, S., Mavrouli, M., Carydis, P., Agorastos, K., \& Lekkas, E. (2021). The March 2021 Thessaly earthquakes and their impact through the prism of a multi-hazard approach in disaster management. Bulletin of the Geological Society of Greece, 58, 1-36.

Papadimitriou, P., Kapetanidis, V., Karakonstantis, A., Spingos, I., Kassaras, I., Sakkas, V., Kouskouna, V., Karatzetzou, A., Pavlou, K., Kaviris, G., \& Voulgaris, N. (2020). First Results on the Mw=6.9 Samos Earthquake of 30 October 2020. Bulletin of the Geological Society of Greece, 56(1), 251-279.

Papagiannaki, K., Diakakis, M., Kotroni, V., Lagouvardos, K., \& Andreadakis, E. (2019). Hydrogeological and climatological risks perception in a multi-hazard environment: the case of Greece. Water, 11(9), 1770.

Pyles, L., \& Svistova, J. (2015). A critical Discourse Analysis of Haiti earthquake recovery in New York Times articles: Implications for social welfare policies, practices and education. Critical Social Work, $16(1)$.

Ratiani, M., Kitiashvili, A., Labartkava, N., Sadunishvili, P., Tsereteli, E., \& Gvetadze, N. (2012). Teaching disaster risk reduction with interactive methods: Book for head of class teachers (Grades V-IX) (UNICEF). Tbilisi, GA: National Curriculum and Assessment Centre.

Ripp, J. A., Bork, J., Koncicki, H., \& Asgary, R. (2012). The response of academic medical centers to the 2010 Haiti earthquake: the Mount Sinai School of Medicine experience. The American journal of tropical medicine and hygiene, 86(1), 32.

Sapountzaki, K. (2007). Tomorrow in danger - Natural and technological disasters in Europe and Greece (In Greek). Gutenberg.

Savelidis, S. (2005). Risk assessment and crisis management in quality issues (In Greek). Master thesis. Hellenic Open University.

Schiermeier, Q. (2005). Climate change: That sinking feeling. Nature, 435(7043), 732-733.

Selby, D., \& Kagawa, F. (2012). Disaster Risk Reduction in School Curricula: Case Studies from Thirty Countries. UNESCO and UNICEF.

Smith, K. (2013). Environmental Hazards: Assessing Risk and Reducing Disaster (6 ${ }^{\text {th }}$ ed.). Routledge.

Speis, P. D., Andreadakis, E., Diakakis, M., Daidassi, E., \& Sarigiannis, G. (2019). Psychosocial vulnerability and demographic characteristics in extreme flash floods: The case of Mandra 2017 flood in Greece. International Journal of Disaster Risk Reduction, 41, 101285.

UNISDR. (2015). Making development sustainable: the future of disaster risk management, global assessment report on disaster risk reduction. United Nations Office for Disaster Risk Reduction (UNISDR).

Vallianou, K., Alexopoulos, T., Plaka, V., Seleventi, M. K., Skanavis, V., \& Skanavis, C. (2020). Building resilient communities: The traumatic effect of wildfire on Mati, Greece. International Journal of Psychological and Behavioral Sciences, 14(6), 416-423. 
Varlas, G., Anagnostou, M. N., Spyrou, C., Papadopoulos, A., Kalogiros, J., Mentzafou, A., Michaelides, S., Baltas, E., Karymbalis, E., \& Katsafados, P. (2019). A multi-platform hydrometeorological analysis of the flash flood event of 15 November 2017 in Attica, Greece. Remote Sensing, 11(1), 45.

Xanthopoulos, G. (2015). Contemporary approaches to major Natural disasters and reconstruction after them (In Greek). Demeter, 9, 14-17.

Zabaniotou, A., Pritsa, A., \& Kyriakou, E. A. (2021). Observational Evidence of the Need for GenderSensitive Approaches to Wildfires Locally and Globally: Case Study of 2018 Wildfire in Mati, Greece. Sustainability, 13(3), 1556.

Zavlanos, M. (2002). Organizational behavior (In Greek). Stamouli. 